Meta

Journal des traducteurs

Translators' Journal

\title{
The Occurrence of Calque in Translation Scripts
}

\section{Penelope M. Sewell}

Volume 46, numéro 3, septembre 2001

URI : https://id.erudit.org/iderudit/004120ar

DOI : https://doi.org/10.7202/004120ar

Aller au sommaire du numéro

\section{Éditeur(s)}

Les Presses de l'Université de Montréal

ISSN

0026-0452 (imprimé)

1492-1421 (numérique)

Découvrir la revue

Citer cette note

Sewell, P. M. (2001). The Occurrence of Calque in Translation Scripts. Meta, 46(3), 607-615. https://doi.org/10.7202/004120ar

\section{Résumé de l'article}

Pour l'auteur, il semblerait que les étudiants font un plus grand nombre de calques en traduisant du français à l'anglais que de l'anglais au français. Cet article explore d'abord la notion de calque pour en arriver à une définition opérationnelle, ensuite identifie et discute les cas de calques dans deux textes traduits durant des conditions d'examen, c'est-à-dire sans dictionnaire. Les étudiants sont ensuite divisés en deux catégories selon leur L1 et les observations sont faites sur le nombre de calques exposés par chaque groupe. Les résultats soulèvent un certain nombre de questions auxquelles seulement des recherches plus approfondies peuvent répondre.
Ce document est protégé par la loi sur le droit d'auteur. L'utilisation des services d'Érudit (y compris la reproduction) est assujettie à sa politique d'utilisation que vous pouvez consulter en ligne.

https://apropos.erudit.org/fr/usagers/politique-dutilisation/ 


\section{BLOC-NOTES}

\section{The Occurrence of Calque in Translation Scripts}

\begin{abstract}
RÉSUMÉ
Pour l'auteur, il semblerait que les étudiants font un plus grand nombre de calques en traduisant du français à l'anglais que de l'anglais au français. Cet article explore d'abord la notion de calque pour en arriver à une définition opérationnelle, ensuite identifie et discute les cas de calques dans deux textes traduits durant des conditions d'examen, c'est-à-dire sans dictionnaire. Les étudiants sont ensuite divisés en deux catégories selon leur $L_{1}$ et les observations sont faites sur le nombre de calques exposés par chaque groupe. Les résultats soulèvent un certain nombre de questions auxquelles seulement des recherches plus approfondies peuvent répondre.
\end{abstract}

\begin{abstract}
It seemed to the author that students were making a larger number of calques when translating from French into English than from English into French.This paper first explores the notion of calque in order to arrive at an operational definition, then identifies and discusses instances of calque in two texts translated under examination conditions, without dictionaries. The students are then divided into categories according to their $\mathrm{L}_{1}$ and observations are made about the amount of calquing exhibited by each group. The results raise a number of questions to which only further research can find an answer.
\end{abstract}

\section{MOTS-CLÉS/KEYWORDS}

bilingualism, calque, comparative stylistics, error analysis.

\section{Introduction}

It seemed to the author that students were making a larger number of calques when translating from French into English than from English into French. This paper first explores the notion of calque in order to arrive at an operational definition, then identifies and discusses instances of calque in two texts translated under examination conditions, without dictionaries. The students are then divided into categories according to their L1 and observations are made about the amount of calquing exhibited by each group. The results raise a number of questions to which only further research can find an answer.

\section{Background}

In the French Department at Birkbeck College, translation is only rarely used as a tool in the teaching of French. Instead, we have theorised it as a skill in its own right and offer a final-year option in translation from and into French, with emphasis on translation strategies and contrastive stylistics.

Over the years it has become apparent that my colleague, who deals with French into English translation, and I, who do the English to French translation, are preoccupied by different problems. I am concerned to ensure adequate exploration of the lexical and syntactic options in French, he, on the other hand, wages a continuing battle against calque. This has prompted me to ask, "Is it the case that translations into French (for the majority, the L2) produce fewer calques than the other way round? If so, why should that be? Where do students whose L1 is not English stand with regard to this phenomenon?" This paper in an enquiry into the nature of calque and a search for confirmation that calque is a more serious problem for people translating into English (L1 for the majority) than the other way. What, though, constitutes a calque and what approach to it have linguists taken?

\section{Studies of calque}

It was Vinay and Darbelnet (1958) who, for me, first put calque on the map, but the idea goes back far further than that. The word comes from the Latin "calcare", meaning to tread, or press, which itself is a derivative of "calx", heel. The word is not passed to us directly, but comes via Italian, (Lewis and Short, 1955).

Chambers (1981) gives "to calque or calk: to copy by rubbing the back with colouring matter and then tracing with a blunt point". Le Petit Robert (1995) says:

- Exact reproduction of a drawing or pattern, obtained by copying (en calquant).

- Literal translation into another language (of a complex expression or a word used figuratively).

It will be seen that neither Chambers nor Le Petit Robert gives any hint of a negative dimension to the idea: we are simply talking about copying and tracing. Le Petit Robert goes on to give the examples lune de miel and gratte-ciel as being calqued on the English "honeymoon" and "skyscraper".

Calque figures among the seven Procédés techniques de la traduction as defined by Vinay and Darbelnet. The first three involve direct transfer from the source language (SL) to the target language (TL), and they are: l'emprunt (borrowing), 
calque, and la traduction littérale (literal translation). "Borrowing" needs little comment. The procedure takes a word or phrase from the SL and uses it as part of the TL. Borrowings in English from French are legion ("pied à terre, cul de sac, honni soit qui mal y pense"), as they are in French from English (le meeting, le stress, le fair-play).

"Literal translation" is the name given to the third procedure which involes translating wordfor-word in cases where the translated phrase is entirely acceptable in the TL. Vinay and Darbelnet give as an example: "I left my spectacles on the table downstairs" translating perfectly adequately as J'ai laissé mes lunettes sur la table en bas.

However, Vinay and Darbelnet's account of the second procedure, calque, has some surprises:

Calque is a particluar kind of borrowing: a phrase is borrowed from the foreign language, and its component parts are translated. $[\ldots]$

It would seem advisable to coin new words using the Greek and Latin basis of our lexicon $[. .$.$] . By doing so, one can avoid painful$ calques such as: Thérapie occupationnelle (Occupational Therapy); Banque pour le Commerce et le Développement; les quatre Grands; le Premier français, and others which, in the minds of some translators, constitute the lowest depths to which one could sink.

(The original text reads: ... qui sont, dans l'esprit de certains traducteurs, l'expression la plus concrète de l'abomination de la désolation).

The note of caution, one might even say panic, is somewhat unexpected. In Vinay and Darbelnet's eyes it is advisable not to calque (i.e. bend TL patterns to mimic SL models), but to create a new word altogether, or to use a word which already exists in the TL. Why the anguish? To go so far as advising the translator to neologise, when the whole idea of neologising was historically abhorrent to the French (viz. Littré's 1877 Dictionnaire de la langue française and the disapproval which was subsequently attached to words bearing his descriptor néol.) shows how resistant to calque Vinay and Darbelnet were. They, of course, write in Canada, where French is a minority language, vulnerable to "take-over" from the ambient anglosaxon culture. They, among the first French-speaking linguists to perceive the threat, would clearly be concerned to save French from becoming English with a French accent. However, metropolitan France is now equally concerned and anxieties about calque are no less strong.

Recent, and more positive-minded, studies of calque, such as those of Chansou (1984: 281285) and Santoyo (1987: 240-249) focus on the neologising power of the calque mechanism as a way of both conveying new concepts to new target audiences and of enriching the vocabulary of the receptor language. Both these writers are concerned to provide an adequate definition of calque, as is Romaine (1995: 55-59), who also discusses other types of lexical borrowing within the context of languages in contact. A study of English calques in Chicano Spanish by Smead and Clegg (1996: 123-130) concludes that "the majority of the forms examined are both formally and semantically convergent and duplicate an existing message-type", an observation which is clearly of interest in a sociolinguistic context, but which again focuses on defining and categorising. A. Duval (1990: 27-33), on the other hand, is more concerned to show the limitations of bilingual dictionaries which function on word-for-word equivalents, whereas, he says, translators need to be aware of words in context and of usage. Duval's insights are more in line with the preoccupations of the present paper, since it is the (inadvertent) production of calque by translators which is the focus here.

Taking into account all the above discussions of classification, I propose as a working definition of calque, that it is the very close, but not necessarily word-for-word, translation into a target language (TL) using TL forms, of forms in a source language.

\section{The related notions of cognate and false friend}

What distinguishes cognates and false friends from calques? Intralinguistic cognates are those words of a language which are formally related to one another, constituting a semasiological field, since each member of that field exhibits some form of the root common to all of them.

\section{Example: direct, director, direction.}

Similarly, all pairs of words across languages which are derived from a common root are cognates.

Examples: appartment/appartement; director/directeur.

Such interlingual cognates can occasionally be real friends, as is the case in the last two examples quoted, but more often, as learners know to their cost, they can be false friends.

False friends are words which look the same, or very similar, in two languages, but whose meanings are different. The unwary translator who assumes similarity of form equals similarity of meaning and who unthinkingly uses the treacherous item in his/her translation thus falls into a classic trap. Simple examples of English-French false friends are "parent/parent; medicine/médecin, 
"location/location". (Only the first two are pairs of cognates.) These, and more complex examples are brilliantly presented in Thody \& Evans (1985), which gives explanations of how such terms are used in French and English.

Both interlingual cognates and false friends can clearly be the source of calques, since both can induce direct word-substitution. A TL calque might be the result of the choice of a cognate or a false friend, as in collège being translated as "college", or une villa being rendered as "a villa". Such calques can be avoided only by constantly being on the alert, and, where necessary, checking in dictionaries. Although componential analysis is clearly not a totally satisfactory tool, as shown by Lyons (1977: 317-335) who warns about the danger of slippage amongst the various levels of analysis, and Saeed (1997: 259-261) who asks the question, "Are the [identified] components psychologically real?", breaking down the meanings of interlingual cognates does help to differentiate them, as the following analysis of "villa" shows.

\begin{tabular}{lcc}
\hline VILLA & & \\
Characteristics & Le Petit Robert & Chambers \\
& 1995 & 1981 \\
rich & $\mathrm{X}$ & \\
holiday house & $\mathrm{X}$ & \\
in Italy (originally) & $\mathrm{X}$ & $\mathrm{X}$ \\
with garden & $\mathrm{X}$ & \\
road & $\mathrm{X}$ & \\
cul de sac & $\mathrm{X}$ & \\
country house (originally) & $\mathrm{X}$ & \\
farmhouse (originally) & & $\mathrm{X}$ \\
subsidiary buildings (originally) & & $\mathrm{X}$ \\
country seat-castle & & $\mathrm{X}$ \\
large detached house & & $\mathrm{X}$ \\
superior, middle-class house & & $\mathrm{X}$ \\
\hline
\end{tabular}

As can be seen, the overlap in meaning is minimal. Having thus checked the words in appropriate dictionaries, the translator would be drawn to considering very carefully how best to translate "villa" for the particular text in hand.

\section{Types of error related to calque}

Can the study of cross-linguistic influences in interlanguages throw any light on the occurrence of calque? Research on interlanguage focuses on performance in an L2 or an L3, and seeks reasons for the production both of target forms which are inappropriately used, and non-target forms (Dewaele, 1998). Thus, in a translation done by a student at Birkbeck College 1996-97, the phrase "an act of revenge" was translated as un acte de ${ }^{*}$ revenge. The form ${ }^{*}$ revenge does not exist in French. The student had no recourse to dictionaries, and one must hypothesise that either she "invented" the form, or that she was actually trying to write revanche but was ignorant of the spelling. It is precisely this sort of L2 error that interlanguage research is concerned with, for the insights such errors give into second language acquisition. However, calque is being defined here as the very close translation into a TL, using TL forms, of forms in a SL, and therefore excludes the type of non-target forms such as ${ }^{\star}$ revenge presented as a French form.

Another example of a calque-related error is that of the student, who, when faced with translating into French "the opening titles" (of a TV show), writes les crédits, presumably thinking that crédits is commonly used in the same way in French as "credits" is in English. The error would be of interest both to a researcher into cross-linguistic influence, and to a translation theorist, although it does not qualify as a true calque.

Both the above examples, taken from English L1 speakers' work, can be attributed to a degree of ignorance of the TL.

In spite of the interest generated by the two preceding examples of calque-related error, this paper is focused on true calques, that is direct translations of an ST word or phrase. Furthermore, because of the particular circumstances of the study, namely the context of a university-level course in translation, and because the question arose out of the perception of error, I must define calque, for the purposes of this study, as the inappropriate very close translation into a TL, using TL forms, of SL forms, thus endorsing, but for different reasons, the worries of Vinay and Darbelnet discussed earlier. Given that definition, the central question being asked is "Is it the case that calque occurs more frequently when students translate into English (L1 for the majority) than when they translate into French?”

\section{The subjects}

Let us now examine two texts translated by a group of 26 students under examination conditions, without recourse to dictionaries. The group was made up as follows:

19 English L1 speakers, of whom one had spent considerable time in France.

3 French L1 speakers, of whom 2 had lived many years in the UK.

2 Anglophone Africans, educated in English, but for whom English was not the L1. One of these had lived some years in a French-speaking African country.

1 German L1 speaker.

1 Mauritian of Cantonese origin, Creole L1 speaker, educated mainly in French. 
I propose first to examine the calques produced by the whole group of students, since the calques in themselves are interesting. Later on, the performance of particular groups of students will be considered separately.

\section{The corpus}

Let us take the English source text first. Students know that they are required to translate as if for a similar readership in the TL. The underlined phrases are the sites of calque.

This article appeared in the Observer on 1.12.96. It has been slightly adapted.

\section{Secrets of the Seat}

The black leather chair and the spotlight which became the symbols of Mastermind were designed to recreate the atmosphere of a wartime interrogation. Bill Wright, $\underline{\text { a former }}$ prisoner of war who devised the show's for$\underline{\text { mat, wanted contestants to feel they were be- }}$ ing grilled under the fiercest pressure.

Although a duplicate chair is kept in case of emergencies, the same original model has been used since 1972, transported around the country by lorry. The duplicate chair has been used in the opening titles and for certain comedy shows. Magnus Manusson has always refused to sit on either chair.

Between filming, the main chair is kept in a secret location in London and guarded closely. In 1979 students at the University of Coleraine "kidnapped" it and demanded a small ransom in aid of Cambodia. After tense negotiations, it was handed back with no money changing hands.

Although Magnusson has always avoided it, he may be forced to sit in the chair for the first time as part of the programme's finale next year. Under the famous spotlight, he is expected to be asked questions on his 25 years as quizmaster by former contestants in a last act of revenge.

Magnusson suggested last night that the BBC should present him with the chair as a "permanent memento of 25 of the happiest years of my life. I would like to put it out to grass in my study."

Possible translation:

222 words

\section{Questions pour un champion}

On avait choisi le fauteuil en cuir noir et le projecteur pour "Mastermind", jeu télévisé bri- tannique, parce qu'on voulait recréer l'ambiance d'un interrogatoire de prisonniers de guerre. Ils en sont devenus les symboles. En effet, le créateur de la mise en scène, Bill Wright, lui-même ancien prisonnier, voulait provoquer chez les concurrents le sentiment d'être cuisinés dans des conditions de tension féroce.

Le fauteuil originel de 1972 figure toujours dans chaque émisison; il est transporté par voie routière de ville en ville. Un deuxième fauteuil existe, certes, en cas de catastrophe, qui a été utilisé, lui, pour filmer le générique des émissions et dans certains sketches comiques. Le présentateur, Magnus Magnusson n'a jamais voulu s'asseoir, ni dans l'un ni dans l'autre.

Entre tournages, le fauteuil principal est déposé dans un endroit secret à Londres, sous haute surveillance. En 1979, les étudiants de l'Université de Coleraine en Irlande, l'ont " $k i d-$ nappé” et ont demandé une petite rançon en faveur du Cambodge. Au terme de négociations difficiles, le fauteuil fut restitué sans paiement de rançon.

Malgré les réticences de Magnusson, il se verra peut-être obligé d'occuper le fauteuil pour la première fois lors de l'ultime émission cette année. Installé sous le fameux projecteur, il répondra à des questions sur les 25 années de l'émission, questions qui seraient posées, comme dernier acte de vengeance, par d'anciens concurrents.

Magnusson a récemment suggéré que la $B B C$ lui fasse don du fauteuil, "souvenir permanent des 25 ans les plus heureux de ma vie. J'aimerais le mettre au vert chez moi dans mon bureau," a-t-il dit.

270 words

This text was translated by students in their final year at university. All but four of the group were mature students.

All calque-like errors of a lexical nature were noted and matched against the adopted definition of calque. Such forms as ${ }^{*}$ deviser (devised the show's format), ${ }^{\star}$ le prisonère (prisoner of war), ${ }^{\star}$ la pressure (the fiercest pressure), ${ }^{\star}$ une émergencie (emergency), ${ }^{\star} l$ 'expectation and ${ }^{\star}$ un acte de revenge are lexical inventions, i.e. "lexemes which are morphologically adapted to the target language but which are never used by native speakers" (Dewaele, 1998: 471) There were ten different lexical inventions, made by ten different students.

Examples of students attempting to calque a word or phrase which is a synonym of the ST phrase were: "a duplicate chair" translated as une chaise double, "guarded closely" became en clôture 
ferme, "around the country" was le long et le large $d u$ pays, "last night" translated as hier nuit and finally décliner l'occasion de for "has always refused". These errors were also excluded.

Calques occurring in the French target text $(\mathrm{n}=9)$

\begin{tabular}{|l|l|l|}
\hline Source text & $\begin{array}{l}\text { Calqued } \\
\text { translation }\end{array}$ & $\begin{array}{l}\text { Number } \\
\text { of tokens }\end{array}$ \\
\hline designed to create & désigner & 2 \\
\hline interrogation & interrogation & 18 \\
\hline a former prisoner & un ancien prisonnier & 8 \\
\hline the show's format & le format & 9 \\
\hline contestant & le contestant & 4 \\
\hline grilled & griller & 1 \\
\hline emergency & émergence & 2 \\
\hline secret location & location secrète & 4 \\
\hline in aid of & $\begin{array}{l}\text { pour l'aide de; à l'aide } \\
\text { de; } \text { en aide de }\end{array}$ & 4 \\
\hline
\end{tabular}

Given the conditions under which this piece was translated, I believe that the crop of calques is rather small. Furthermore, I would expect the number to have been even smaller if an EnglishFrench (or even a monolingual French) dictionary had been available. In order to establish a benchmark with which to compare students' performance on the translation exercise, I used scores from a course entitled "French Language Proficiency 2", taken two years earlier. It was necessary to use this course as 4 of the students had spent the previous year abroad and did not have any French language score for that year. The table is presented later. In the translation into French, there is a tendency for more calques to be made by the more proficient speakers of French than by the less proficient.

The French source text was presented thus:

This is an extract from Albert Camus' 1957 short story, La Femme adultère. Janine and her husband Marcel, a travelling salesman, are a couple of French descent living in Algeria. This scene takes place on a bus.

"Janine!" Elle sursauta à l'appel de son mari. Elle pensa une fois de plus combien ce prénom était ridicule, grande et forte comme elle était. Marcel voulait savoir où se trouvait la mallette d'échantillons. Elle explora du pied l'espace vide sous la banquette et rencontra un objet don't elle décida qu'il était la mallette. Elle ne pouvait se baisser, en effet, sans étouffer un peu. Au collège pourtant, elle était première en gymnastique, son souffle était inépuisable. $Y$ avait-il si longtemps de cela? Vingt-cinq ans. Vingt-cinq ans n'étaient rien puisqu'il lui semblait que c'était hier qu'elle hésitait entre la vie libre et le mariage, hier encore qu'elle pensait avec angoisse à ce jour où, peut-être, elle vieillirait seule. Elle n'était pas seule, et cet étudiant en droit qui ne voulait jamais la quitter se trouvait maintenant à ses côtés. Elle avait fini par l'accepter, bien qu'il fût un peu petit et qu'elle n'aimât pas beaucoup son rire avide et bref, ne ses yeux noirs trop saillants. Mais elle aimait son courage à vivre, qu'il partageait avec les Français de ce pays. Elle aimait aussi son air déconfit quand les événements, ou les hommes, trompaient son attente. Surtout, elle aimait être aimée, et il l'avait submergée d'assiduités. A lui faire sentir si souvent qu'elle existait pour lui, il la faisait exister réellement. Non, elle n'était pas seule...

242 words

Possible translation

"Janine!" Hearing her husband call made her jump. Not for the first time it struck her what a ridiculous name she had - for someone as tall and as heavily built as she was. Marcel wanted to know where the sample case was. She felt around under the seat with her foot, and it came into contact with something which she decided must be the case. Bending down, she knew, would have made it difficult for her to breathe. And just to think that at school she used to be top of the class in gym, and never got out of breath. Was that really such a long time ago? Twenty-five years. That was no time at all, twenty-five years. It seemed to her only yesterday that she had been in two minds about getting married - or staying free, and only yesterday that she had been dreading the thought of perhaps one day growing old on her own. She was not on her own, and that very same law-student who never wanted to let her out of his sight was now sitting right here beside her. She had eventually said yes, even though he was a bit on the short side, and she didn't much like the eager and ephemeral way he laughed, or his dark bulging eyes. But she did like his getup-and-go attitude to life, something he shared with the other Frenchmen living here in Algeria. She also like the way he looked so crestfallen when events, or other people, failed to live up to his expectations. But most of all what she liked was being loved, and in his attentions he had been assiduous to the point of overwhelming her. By making her feel time and time again that she did exist for him, he succeeded in actually making her exist. No, she was not on her own...

308 words 
Contrary to the Mastermind text, I did not have to worry so much about the exact nature of the items I harvested, since there were no "invented" forms. I ignored instances of incomprehensible English and of mistranslations of the ST. I followed my colleague's indication of $\mathrm{C}$ for calque and made sure he had been consistent in his labelling.

Calques occurring in the english target text $(n=18)$

\begin{tabular}{|l|l|c|}
\hline Source text & $\begin{array}{l}\text { Sample of calqued } \\
\text { translation }\end{array}$ & $\begin{array}{c}\text { Number } \\
\text { of tokens }\end{array}$ \\
\hline l'appel & the call (noun) & 3 \\
\hline grande et forte & big and strong & 10 \\
\hline explorer du pied & explored with her foot & 3 \\
\hline l'espace vide & the empty space & 19 \\
\hline la banquette & the bench & 5 \\
\hline étouffer & stifling herself & 1 \\
\hline collège & college & 15 \\
\hline inépuisable & inexhaustible & 4 \\
\hline avec angoisse & with anguish & 3 \\
\hline cet étudiant & that student & 4 \\
\hline $\begin{array}{l}\text { ne voulait jamais } \\
\text { la quitter }\end{array}$ & $\begin{array}{l}\text { never wanted } \\
\text { to leave her }\end{array}$ & 15 \\
\hline l'accepter & accept(ed) him & 13 \\
\hline rire avide & greedy laugh & 4 \\
\hline bref & short laugh & 11 \\
\hline ses yeux noirs & his black eyes & 15 \\
\hline son courage à vivre & his courage... & 3 \\
\hline de ce pays & $\begin{array}{l}\text { in that country/ } \\
\text { of this country }\end{array}$ & 2 \\
\hline trompaient son attente & betrayed/deceived & 3 \\
\hline & & \\
\hline
\end{tabular}

I have some hesitation over "son rire bref". One can, I think, talk about a laugh that is "short and gutteral". However, as phrased in these scripts, the word "short" did not seem appropriate, so I have retained this item.

None of these calques appears to be due to a misunderstanding of the French, and only rarely was it clear, among the calques, that there was inadequate mastery of English. This is not to say that there were no other instances of lack of mastery of English, only that within the domain of the 18 sites of calque, English was not a serious problem.

Let us look briefly at the items with high scores.

Grande et forte. "fort" is assumed to mean "strong", and its many other meanings ignored. The Petit Robert devotes a whole page to the word.

L'espace vide. This phrase is better omitted in English. Among the possible reasons for this are, firstly, that English prepositions are "stronger" than French ones, so that "under" carries as much weight as "l'espace vide"
(Vinay \& Darbelnet, 1958, Chapter 2), and, secondly, that French needs to "reify" concepts i.e. name them, more than English does (Vinay \& Darbelnet, 1958, Chapter 2).

Collège. When you are working under pressure you perhaps do not stop to think what "collège" really designates - you are only too grateful for the gift of a clear equivalent. Alas, you are betrayed.

Ne voulait jamais la quitter. The meaning is surely "never wanted to let her out of his sight", not that he had pledged his eternal companionship. To translate "la quitter" by "to leave her" is inappropriate.

L'accepter. English is unlikely to "accept a person". One might accept a proposal, but not a suitor. This is a question of usage.

Ses yeux noirs. Black eyes, in English, belong to the world of violence and bruising.

All 18 examples of calque are typical examples of surface translation. To use the classic diagram, the translators have gone straight from Source Text (ST) to Target Text (TT), schematised thus:

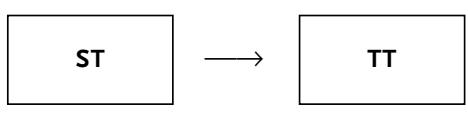

A year's hard training has not prevented such "surface" translating. Yet in class we have focused on analysing the ST so that ambiguity and lack of comprehension are resolved. Time is spent putting the ST through a process of paraphrasing and analysis, before the translator is ready to find the target wording. To more accurately reflect the methodology of the course, the above diagram should be altered as follows, where the "cognitive processing" box represents the all-important stage of ST analysis:

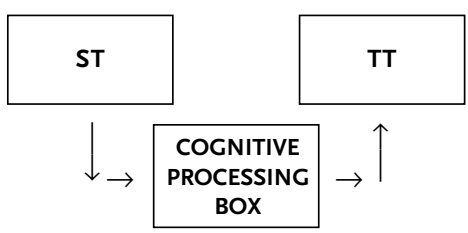

Under examination conditions what has happened? The pressure has resulted in a mechanical word-for-word transfer, with rather sorry consequences. It is not just students who are vulnerable to this phenomenon. In a study of professional translators at work, Janet Fraser (1994) notes that her subjects did not read the whole text through 


\begin{tabular}{|c|c|c|c|c|}
\hline Subject & $\begin{array}{l}\text { Flp2 score } \\
\text { (out of 100) }\end{array}$ & $\begin{array}{l}\text { Calques into } \\
\text { French }\end{array}$ & $\begin{array}{l}\text { Calques into } \\
\text { English }\end{array}$ & Comment \\
\hline \multicolumn{5}{|c|}{ Students with L1 English } \\
\hline 1. & 70 & 2 & 3 & \\
\hline 2. & 65 & 2 & 7 & \\
\hline 3. & 62 & 1 & 5 & \\
\hline 4. & 61 & 2 & 9 & Partly lives in France \\
\hline 5. & 61 & 0 & 5 & \\
\hline 6. & 60 & 1 & 4 & \\
\hline 7. & 59 & 2 & 6 & \\
\hline 8. & 58 & 1 & 7 & \\
\hline 9. & 57 & 0 & 2 & \\
\hline 10. & 57 & 1 & 3 & \\
\hline 11. & 56 & 1 & 6 & \\
\hline 12. & 56 & 2 & 5 & \\
\hline 13. & 53 & 0 & 5 & \\
\hline 14. & 53 & 2 & 3 & \\
\hline 15. & 50 & 0 & 5 & \\
\hline 16. & 46 & 2 & 3 & \\
\hline 17. & 45 & 1 & 5 & \\
\hline 18. & 43 & 1 & 5 & \\
\hline 19. & 42 & 1 & 1 & \\
\hline \multicolumn{5}{|c|}{ Averages: } \\
\hline \multicolumn{5}{|c|}{ Students with L1 French } \\
\hline 20. & 72 & 2 & 6 & Lived long in the UK \\
\hline 21. & 72 & 1 & 4 & Lived long in the UK \\
\hline 22. & 71 & 0 & 7 & \\
\hline \multicolumn{5}{|c|}{ Averages: } \\
\hline \multicolumn{5}{|c|}{ Students with neither English nor French as L1 } \\
\hline 23. & 61 & 0 & 9 & From Ghana \\
\hline 24. & 48 & 0 & 3 & From Uganda \\
\hline 25. & 60 & 0 & 10 & From Mauritius \\
\hline 26. & 59 & 1 & 4 & From Germany \\
\hline \multirow{2}{*}{\multicolumn{2}{|c|}{ Averages: }} & 0.25 & \multicolumn{2}{|l|}{6.5} \\
\hline & & 26 & \multicolumn{2}{|l|}{132} \\
\hline \multicolumn{2}{|c|}{ Overall averages: } & 1.00 & \multicolumn{2}{|l|}{5.07} \\
\hline \multicolumn{2}{|c|}{ Number of different calques: } & 9 & \multicolumn{2}{|l|}{18} \\
\hline
\end{tabular}

before plunging into the translation, and admitted to guilty consciences over the fact. Fraser noted "a clear tendency not to establish meaning in advance through prior reading." Let us hope that with professionals (as with teachers) there are sufficient checks and balances to eliminate errors.

Are particular categories of student more likely to calque than others, either when translating into L1 or into L2? One might expect highly proficient users of both languages to calque less, and students who are weak in either one of them to calque more, out of ignorance. The columns in the table below give the number assigned to the subject, his/her L1, the score obtained on a French
Language Proficiency course (called FLP2) in 1995 , the number of calques made by the student when translating the first examination text into French, and finally the number of calques made by the student when translating the second examination text into English. I have placed the subjects in rank order according to the score on FLP2.

The first observation is that the overall totals of calques differ greatly and a t-test suggests that this difference is statistically significant $(\mathrm{t}(25)=$ $8.66, \mathrm{p}<0.0001)$. There were 26 calques made into French ( 9 different items), and 132 made into English (18 different items). Even if one adds the number of invented forms (not true calques) to 
the French total, it still only comes to 36 . It would seem, therefore, that students are far more likely to calque when translating into English. Although my sample of non-English L1 speakers is small, it is the case with every single one of them, whether they have French as L1, an African language as L1, but educated in English, or have Creole (with partial French education) or German as L1, all made more calques when translating into English than into French (see figure 1).

FIGURE 1

Average Number of Calques into English and French (Mean and Standard Deviation)

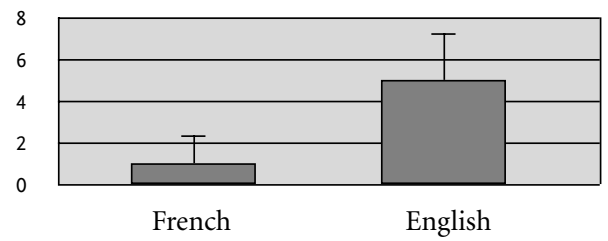

I had at first hypothesised that the larger number of English calques was the prerogative of L1 English speakers, who might be less able to monitor their output in their own language than in a foreign one. This is not borne out by my figures since all the non L1 English speakers also made more calques into English.

Could the figures be reflecting particular characteristics inherent in French and in English which make one language more prone to abuse of this type than the other? It seems hardly likely. The figures may of course be a function of these particular texts, and yet this whole enquiry started because of the very observation that students regularly produced more calques when translating into English than into French, an observation which would indicate that these texts are not untypical in their yield of calques. An analysis of variance (ANOVA) reveals that the $\mathrm{L} 1$ of the subject has no significant effect on the number of calques produced either in French (degrees of freedom $=2$, $23 ; \mathrm{F}=2.36 ; \mathrm{p}=\mathrm{ns})$ or in English $(\mathrm{df}=2,23 ; \mathrm{F}=$ $1.288 ; \mathrm{p}=\mathrm{ns})$.

Another observation on the above table is that it seems that the more proficient speakers of French are more likely to calque than the less proficient ones. Taking FLP2 scores as our reference, we note that the average score was $57.6 \%$. Fourteen students scored higher than the mean, 12 scored lower, and the calque distribution is as follows:

\begin{tabular}{|l|c|c|c|c|}
\hline $\begin{array}{l}\text { Students' scores } \\
\text { on FLP2 (1995) }\end{array}$ & \multicolumn{2}{|c|}{$\begin{array}{c}\text { Calques } \\
\text { into French }\end{array}$} & \multicolumn{2}{c|}{$\begin{array}{c}\text { Calques } \\
\text { into English }\end{array}$} \\
\hline & Mean & S.D. & Mean & S.D. \\
\hline $\begin{array}{l}\text { Above average } \\
(\mathrm{n}=14)\end{array}$ & 1.07 & 0.82 & 6.14 & 2.14 \\
\hline $\begin{array}{l}\text { Below average } \\
(\mathrm{n}=12)\end{array}$ & 0.91 & 0.79 & 3.83 & 0.44 \\
\hline
\end{tabular}

An ANOVA reveals that in the translation into French, the average number of calques is marginally higher amongst the above-average students but that this difference is not statistically significant $(\mathrm{df}=1,24 ; \mathrm{F}=0.234 ; \mathrm{p}=\mathrm{ns})$. When students are translating into English, however, a significant difference does appear, the average number of calques being considerably higher amongst the above-average students $(\mathrm{df}=1,24 ; \mathrm{F}=9.688$; $\mathrm{p}<$ 0.005). It follows, in this sample at least, that the students who had earlier achieved above-average scores in French were more prone to calque (particularly into English) than the weaker students. Indeed, on an anecdotal level, and talking of the whole non-French L1 group, the students who made the most calques into English (between 7 and 10) were those with a high degree of bilingualism based on communicative needs. That is, they had learned their French in a French environment and had clearly not acquired an awareness of the independence of the two different systems.

As regards the three French L1 speakers, it is a mystery why the calquing into English should be thus prevalent.

\section{CONCLUSION}

All-in-all, the study of inappropriate calquing by translators is of interest at several different levels: it highlights contrasting features in the two languages; it throws light on how students translate; it poses questions about the nature of students' competence in either language and about their linguistic awareness as highly proficient users of both languages. We have, in the past, had pronounced alienation from our course in translation from students who felt threatened when their English (which was their L1 or was a language running a close second in bilingual or multilingual students) was questioned. It would seem that our work creates some deep insecurities, but then, studies such as the present one would indicate that such questioning is justified.

Penelope M. Sewell University of London, London, United Kingdom

\section{REFERENCES}

Chambers Twentieth Century Dictionary, (1981): Edinburgh. 
Chansou, M. (1984): "Calques et créations linguistiques”, Meta 29/3, pp. 281-285.

Dewaele, J-M. (1998): "Lexical Inventions: French Interlanguage as L2 versus L3", Applied Linguistics 19/4, pp. 471-490.

Duval, A. (1990): "Nature et valeur de la traduction dans les dictionnaires bilingues", Cahiers de lexicologie 56/57 pp. 27-33.

Fraser, J. (1994): Translating Practice into Theory: a Practical Study of Quality in Translator Training, London, Proceedings of the 7th Annual Conference of the Institute of Translation and Interpreting.

Le Petit Robert, (1995): Paris, Le Robert.

Lewis, C. \& C. Short, (1955); A Latin Dictionary, Oxford, Oxford University Press.

Littré, P. (1877): Dictionnaire de la langue française, Paris, Hachette.

Lyons, J. (1977): Semantics, Cambridge, Cambridge University Press.

Romaine, S. (1995): Bilingualism, Second Edition, Oxford, Blackwell.

SAeEd, J. (1997): Semantics, Oxford, Blackwell.

SAntoyo, J-C. (1987): "Calques et créations linguistiques”, Meta, 32/3, pp. 240-249.

Smead, R. and J. Clegg (1996): "English Calques in Chicano Spanish", Spanish in Contact, Issues in Bilingualism, A. Roca \& J. Jensen (eds), Somerville, USA, Cascadilla Press.

Thody, P. \& H. Evans (1985): Faux amis and Key Words, London, Athlone.

Vinay, J-P. \& J. Darbelnet (1958): Stylistique comparée du français et de l'anglais, Paris, Didier. 